Article

\title{
Efficient Removal of Copper Ion from Wastewater Using a Stable Chitosan Gel Material
}

\author{
Zujin Yang ${ }^{1,2, * \mathbb{D}}$, Yuxin Chai ${ }^{1,2}$, Lihua Zeng ${ }^{3}$, Zitao Gao ${ }^{1}$, Jianyong Zhang ${ }^{3}{ }^{\mathbb{D}}$ and \\ Hongbing $\mathrm{Ji}^{2,4,5, * \mathbb{D}}$ \\ 1 School of Chemical Engineering and Technology, Sun Yat-sen University, Zhuhai 519082, China; \\ chaiyx@mail2.sysu.edu.cn (Y.C.); gaozt@mail2.sysu.edu.cn (Z.G.) \\ 2 Huizhou Research Institute of Sun Yat-sen University, Huizhou 516216, China \\ 3 School of Materials Science and Engineering, MOE Laboratory of Polymeric Composite and Functional \\ Materials, Sun Yat-sen University, Guangzhou 510275, China; Zenglh8@mail2.sysu.edu.cn (L.Z.); \\ zhjyong@mail.sysu.edu.cn (J.Z.) \\ 4 Fine Chemical Industry Research Institute, The Key Laboratory of Low-carbon Chemistry \& Energy \\ Conservation of Guangdong Province, School of Chemistry, Sun Yat-sen University, \\ Guangzhou 510275, China \\ 5 School of Chemical Engineering, Guangdong University of Petrochemical Technology, \\ Maomen 525000, China \\ * Correspondence: yangzj3@mail.sysu.edu.cn (Z.Y.); jihb@mail.sysu.edu.cn (H.J.)
}

Academic Editor: Massimiliano Fenice

Received: 22 October 2019; Accepted: 18 November 2019; Published: 20 November 2019

\begin{abstract}
Gel adsorption is an efficient method for the removal of metal ion. In the present study, a functional chitosan gel material (FCG) was synthesized successfully, and its structure was detected by different physicochemical techniques. The as-prepared FCG was stable in acid and alkaline media. The as-prepared material showed excellent adsorption properties for the capture of $\mathrm{Cu}^{2+}$ ion from aqueous solution. The maximum adsorption capacity for the FCG was $76.4 \mathrm{mg} / \mathrm{g}$ for $\mathrm{Cu}^{2+}$ ion $(293 \mathrm{~K})$. The kinetic adsorption data fits the Langmuir isotherm, and experimental isotherm data follows the pseudo-second-order kinetic model well, suggesting that it is a monolayer and the rate-limiting step is the physical adsorption. The separation factor $\left(R_{\mathrm{L}}\right)$ for Langmuir and the $1 / n$ value for Freundlich isotherm show that the $\mathrm{Cu}^{2+}$ ion is favorably adsorbed by FCG. The negative values of enthalpy $\left(\Delta H^{\circ}\right)$ and Gibbs free energy $\left(\Delta G^{\circ}\right)$ indicate that the adsorption process are exothermic and spontaneous in nature. Fourier transform infrared (FTIR) spectroscopy and x-ray photoelectron spectroscopy (XPS) analysis of FCG before and after adsorption further reveal that the mechanism of $\mathrm{Cu}^{2+}$ ion adsorption. Further desorption and reuse experiments show that FCG still retains $96 \%$ of the original adsorption following the fifth adsorption-desorption cycle. All these results indicate that FCG is a promising recyclable adsorbent for the removal of $\mathrm{Cu}^{2+}$ ion from aqueous solution.
\end{abstract}

Keywords: functional chitosan gel; $\mathrm{Cu}^{2+}$ ion; adsorption; mechanism; reuse experiment

\section{Introduction}

Water pollution caused by heavy metal ion poses a significant threat to environment and human health due to its non-degradability and toxicity $[1,2] . \mathrm{Cu}^{2+}$ ion usually exists in wastewaters of many industries including mining, metallurgical, printed circuits, pipe corrosion, and metal plating industries, etc. [3,4]. However, improper disposal of wastewaters containing $\mathrm{Cu}^{2+}$ ion can bring human health issues and serious environmental problems. According to the U.S. Environmental Protection Agency (EPA), the maximum acceptable concentration of $\mathrm{Cu}^{2+}$ ion in drinking water is $1.3 \mathrm{mg} / \mathrm{L} \mathrm{[5]}$. An excessive amount of $\mathrm{Cu}^{2+}$ ion in the human body could cause serious harm to the kidneys or 
liver [6,7]. Therefore, developing an efficient adsorbent is necessary to remove $\mathrm{Cu}^{2+}$ ion from aqueous solution. Many techniques have been used for the removal of $\mathrm{Cu}^{2+}$ ion from various industrial effluents, such as chemical precipitation, ion exchange, membrane filtration, and adsorption [8-10]. Among these methods, biosorption offers an effective method for the removal of $\mathrm{Cu}^{2+}$ ion from aqueous solution because it has obvious advantages, such as good stability and selectivity, biocompatibility, and biodegradability [11,12].

Chitosan is produced by deacetylation of chitin, which is the second most abundant natural polymer in nature, after cellulose. It has unique properties among biopolymers due to the presence of the amino and hydroxyl groups, and it is extensively applied in wastewater treatment containing heavy metals $[13,14]$. However, its practical application has been restricted by poor stability in acid solution $[15,16]$. Chemical modification has been used to stabilize chitosan in acid solution by using cross-linking reagents, such as formaldehyde, glutaraldehyde, glyoxal, epichlorohydrin, ethylene glycondiglycidyl ether, and isocyanates $[17,18]$. The materials offer some obvious advantages, such as their chemical stability, large specific surface area, and abundant pore-size distribution compared to other adsorbents. For these characteristics, the cross-linked chitosan gels have been applied for the removal of heavy metal ions from aqueous solution [19-21]. However, the immobilization process during the cross-linking reaction would result in the decrease of some adsorption sites, reducing adsorption capacity. However, remaining amine groups offer a promising method to improve the adsorption of pollutants in wastewater [22,23]. Reduction to active functional groups from cross-linking groups has been rarely reported in the previous literature.

In the present work, we converted chitosan power into an insoluble polymer by cross-linking reaction with glyoxal (Gly), which is a promising cross-linker because of its desirable properties [24]. The obtained polymer was further reduced with sodium borohydride $\left(\mathrm{NaBH}_{4}\right)$ to obtain functional chitosan gel material (FCG) (Scheme 1). The resulting FCG was analyzed by Brunau-Emmet-Teller (BET) analysis, Fourier transform infrared spectra (FTIR), solid-state nuclear magnetic resonance (NMR), scanning electronic microscope (SEM), thermogravimetric analysis (TGA), and X-ray photoelectron spectroscopy (XPS). The effects of $\mathrm{pH}$, contact time, ionic strength, and temperature on the adsorption capacity are tested, and the adsorption properties of FCG are also evaluated, $\mathrm{using} \mathrm{Cu}^{2+}$ ion as the model ion. Finally, the adsorption mechanism is discussed, according to the XPS and FTIR analyses.

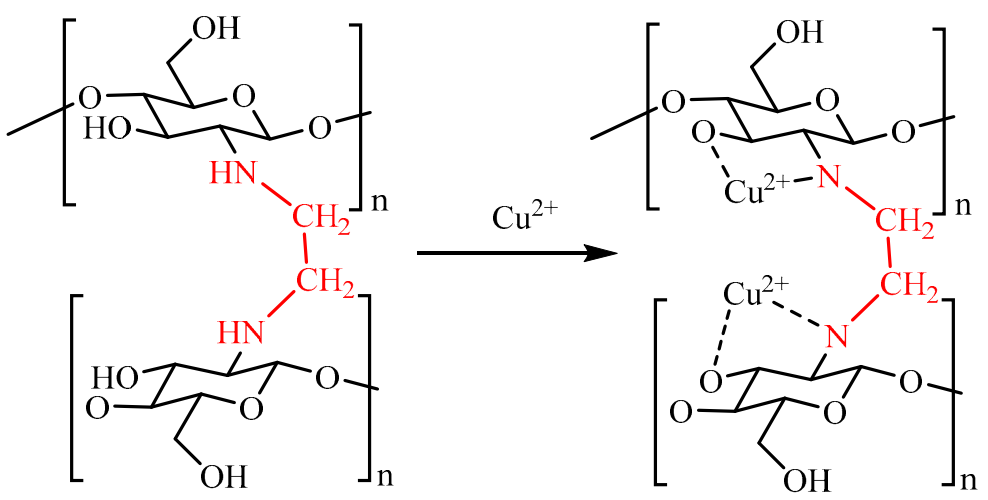

Scheme 1. Adsorption mechanism of FCG with $\mathrm{Cu}^{2+}$ ion.

\section{Results and Discussion}

\subsection{Characterization of FCG}

As displayed in Figure 1, FCG gel was obtained by reacting chitosan with glyoxal in acetic acid aqueous solution. The obtained polymer was further reduced with $\mathrm{NaBH}_{4}$ saturated solution to obtain a white three-dimensional porous gel. For comparison, chitosan and FCG were soaked in distilled water, $2 \%$ acetic acid, or $\mathrm{NaOH}(0.1 \mathrm{~mol} / \mathrm{L})$ for 1 day, at room temperature (RT). As shown in Table S1, there were no significant changes for FCG, indicating that it is stable in acidic or basic solution at 
RT. Thus, the stability of FCG is due to the formation of C-N covalent bonding. In addition, the low swelling behavior of FCG demonstrates that it can be applied for the adsorption experiments.

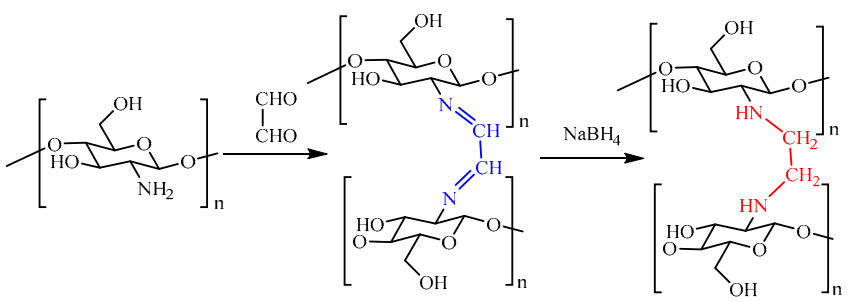

Figure 1. The synthesis procedure of functional chitosan gel (FCG).

Figure $\mathrm{S} 1$ shows $\mathrm{N}_{2}$ adsorption-desorption isotherms at $77 \mathrm{~K}$ and pore-size distribution for chitosan and FCG. As shown in Table S2, the specific surface area of FCG $\left(2.53 \mathrm{~m}^{2} / \mathrm{g}\right)$ is much higher than that of chitosan $\left(0.58 \mathrm{~m}^{2} / \mathrm{g}\right)$. The average pore diameter and total pore volume of chitosan and FCG are $19.88 \mathrm{~nm}, 0.00269 \mathrm{~cm}^{3} / \mathrm{g}$, and $4.63 \mathrm{~nm}, 0.0829 \mathrm{~cm}^{3} / \mathrm{g}$, respectively. It can be seen that the surface area and total pore volume increase, but the average pore diameter decrease, after reaction, implying that the synthesized FCG is favorable for the adsorption of metal ions. Based on the IUPAC results, $\mathrm{N}_{2}$ adsorption of FCG belongs to type II. It exhibits a significant rise of uptake at the relative pressure $\left(\mathrm{P} / \mathrm{P}^{\circ}=0\right.$ to 0.05$)$, and steadily rises within the region $0.1<\mathrm{P} / \mathrm{P}^{\circ}<0.9$ and rapidly climbs in the range of $\mathrm{P} / \mathrm{P}^{\circ}>0.9$, demonstrating that the FCG is micropores [25]. The results indicate that the improved porosity is beneficial for the penetration of $\mathrm{Cu}^{2+}$ ion into the network of FCG.

As Figure 2a shows, chitosan has a smooth and heterogeneous surface with micropore structure, which has been confirmed by its BET surface area. FCG has a much more wrinkled and irregular structure than non-cross-linked chitosan, and large pore structures can be clearly seen in Figure $2 \mathrm{~b}$. However, after adsorption of $\mathrm{Cu}^{2+}$ ion, the strong and specific binding of $\mathrm{Cu}^{2+}$ involving most of the $-\mathrm{NH}$ and $-\mathrm{OH}$ groups lead to a smooth surface structure (Figure 2c). In addition, FCG still retains their original connected three-dimensional structure, verifying its repeatability.

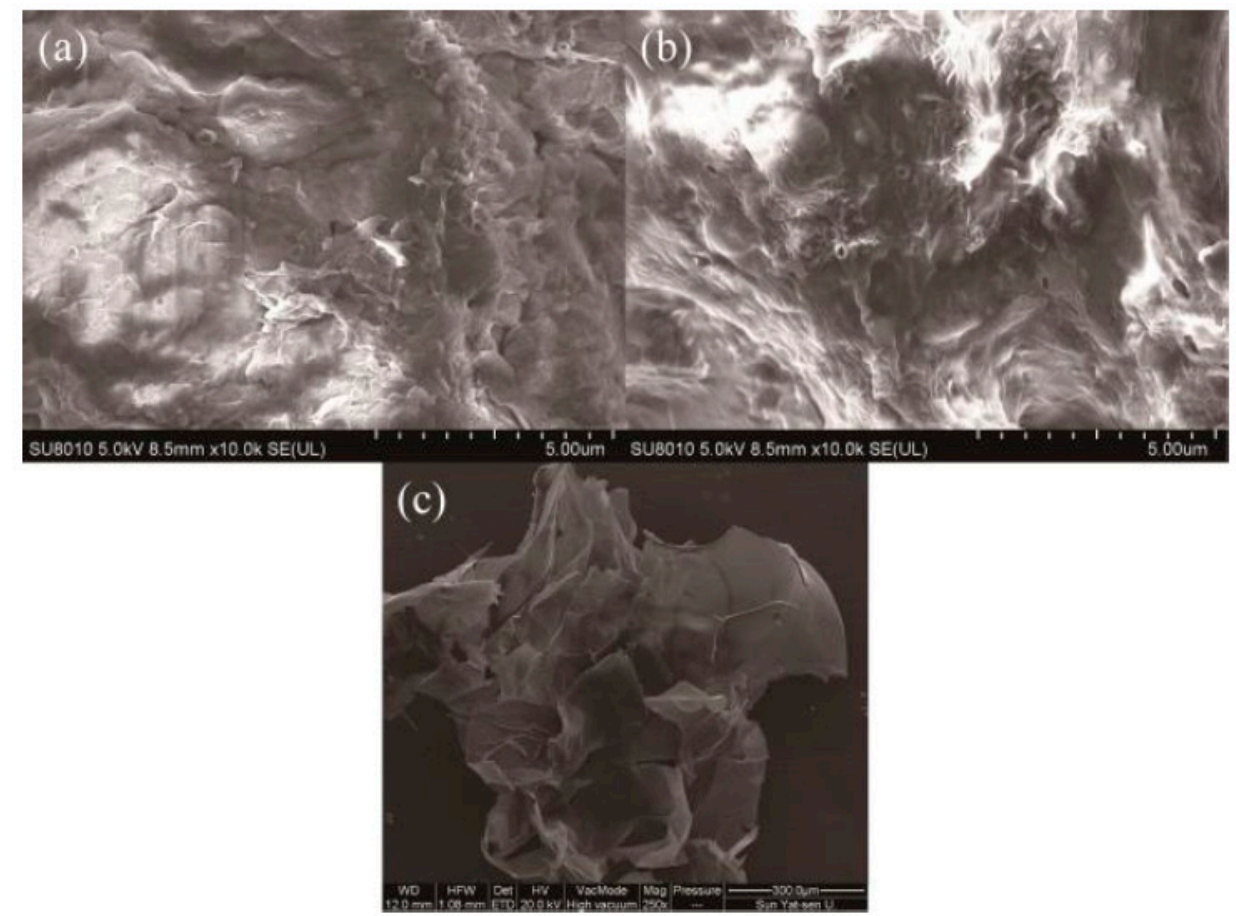

Figure 2. SEM micrographs of chitosan (a), FCG, (b) and FCG after adsorption (c). 
Figure 3 shows TG curves of chitosan and FCG. The first mass-loss stages from about 323 to $393 \mathrm{~K}$ are due to the loss of water adsorbed on the surface of the adsorbents. The second stage begins at $553 \mathrm{~K}$ with mass loss of $65 \%$ due to heat decomposition of chitosan. The TGA curve for FCG exhibits that thermal degradation starts at $393 \mathrm{~K}$ with $42 \%$ mass loss, which is lower than that of chitosan. The result implies that FCG is less stable than chitosan, which may be due to a decrease of intramolecular hydrogen bonding. However, the thermal stability of FCG is sufficient for the material to be used in wastewater treatment.

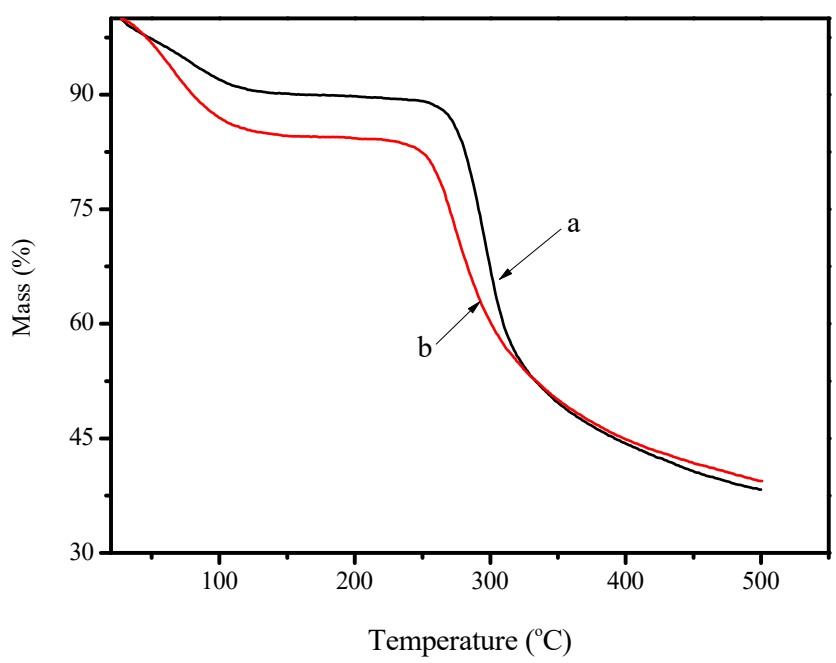

Figure 3. TGA curves of chitosan (a) and FCG (b).

Figure 4 shows the FTIR spectra of chitosan, FCG $(\mathbf{b})$, and FCG after adsorption of $\mathrm{Cu}^{2+}$ ion (c). the bands of $3430 \mathrm{~cm}^{-1}$ (-OH stretching vibration), $1570 \mathrm{~cm}^{-1}\left(\mathrm{~N}-\mathrm{H}\right.$ bending vibration of $-\mathrm{NH}_{2}$ groups), and $1032 \mathrm{~cm}^{-1}$ (O-H bending vibration) represent the characteristic absorption peak of chitosan (Figure 4a) [26]. After it reacts with Gly and is further reduced by $\mathrm{NaBH}_{4}$, the $\mathrm{N}-\mathrm{H}$ bending vibration of chitosan at $1570 \mathrm{~cm}^{-1}$ is obviously weakened, and a new peak is observed at $1640 \mathrm{~cm}^{-1}$, due to the formation of $-\mathrm{NH}-\mathrm{CH}_{2}$ group. The presence of the $-\mathrm{NH}-\mathrm{CH}_{2}$ group is confirmed by $\mathrm{C}-\mathrm{H}$ stretching vibration at $2927 \mathrm{~cm}^{-1}$. The results indicate that Gly monomer is grafted onto the backbone of chitosan (Figure $4 \mathrm{~b}$ ). In order to further illustrate the adsorption mechanism of FCG for $\mathrm{Cu}^{2+}$ ion, the FTIR spectrum of FCG after adsorption was recorded. Compared with the spectrum of FCG before adsorption, the $\mathrm{NH}$ stretching vibration of $-\mathrm{NH}-\mathrm{CH}_{2}$ group at $1570 \mathrm{~cm}^{-1}$ was shifted to $1520 \mathrm{~cm}^{-1}$ and decreased in intensity after the adsorption of $\mathrm{Cu}^{2+}$ ion, indicating that the $\mathrm{NH}$ and $\mathrm{OH}$ groups complexed with the $\mathrm{Cu}^{2+}$ ion (Figure 4c).

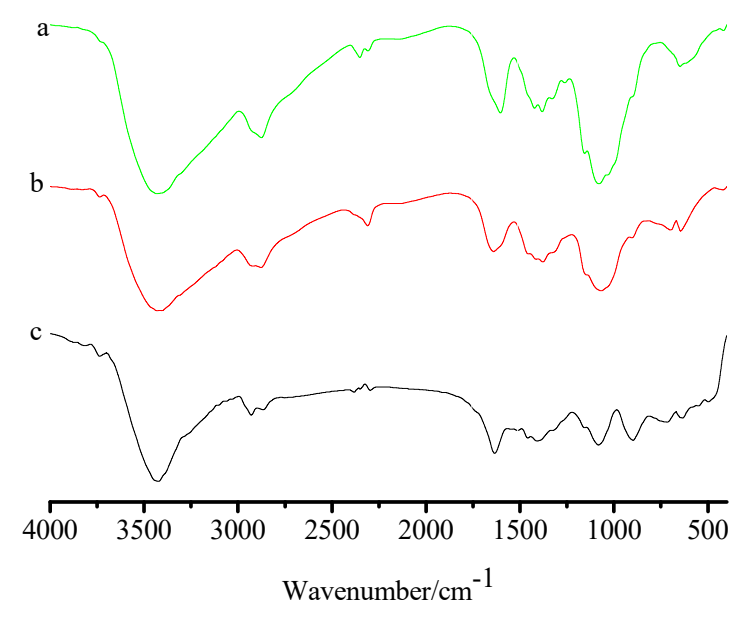

Figure 4. FTIR spectra of chitosan (a), FCG (b), and FCG after adsorption of $\mathrm{Cu}^{2+}$ ion (c). 
Solid-state ${ }^{13} \mathrm{C}$ NMR spectra of chitosan and FCG are shown in Figure 5 . The chemical shift of chitosan reveals six ${ }^{13} \mathrm{C}$ signals at $\delta 57 \mathrm{ppm}(\mathrm{C}-\mathrm{N}), 60 \mathrm{ppm}(\mathrm{C} 2, \mathrm{C} 6), 75 \mathrm{ppm}(\mathrm{C} 3, \mathrm{C} 4, \mathrm{C} 5)$, and 102 ppm (C1), respectively [27]. FCG has similar structure characteristics with chitosan. However, peak for FCG at $\delta 54$ ppm implies the formation of $\mathrm{C}-\mathrm{N}$ bond (C7) $[28,29]$.
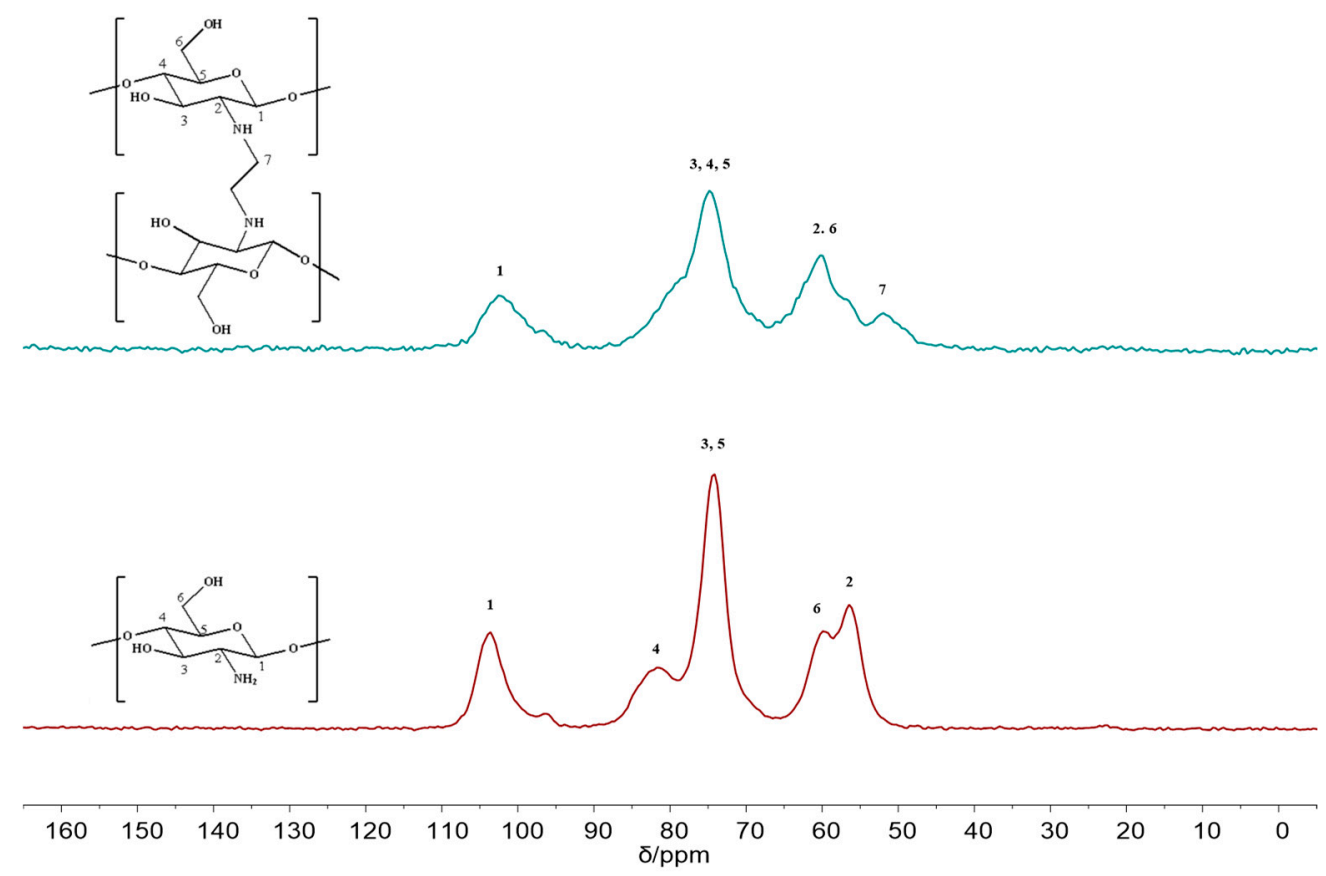

Figure $5 .{ }^{13} \mathrm{C} C P-M A S$ spectra of chitosan and FCG.

Figure 6 shows the XPS spectra of FCG before and after the adsorption. It is obvious that the $\mathrm{Cu}_{2 \mathrm{p}}(B E=933.53 \mathrm{eV})$ peak appeared in the spectra of the FCG after the adsorption, implying that the $\mathrm{Cu}^{2+}$ ion was adsorbed on the FCG (Figure 6a). The N1s exhibits a single peak with the bonding energy of $399.12 \mathrm{eV}$ (the $\mathrm{N}$ atom in the NH group, Figure $6 \mathrm{~b}$ ), slightly shifted to $399.68 \mathrm{eV}$ after the adsorption and a new peak appears at $400.94 \mathrm{eV}$ due to the N1s BE of NH2-C groups in the complex compounds of $\mathrm{Cu}^{2+}$ ion with FCG, confirming that the nitrogen atom of $-\mathrm{NH}$ groups could also form surface complexes with $\mathrm{Cu}^{2+}$ ion (Figure 6c). The O1s peaks at $532.08 \mathrm{eV}(\mathrm{C}-\mathrm{O})$ and $532.88 \mathrm{eV}(\mathrm{C}-\mathrm{OH})$ for the FCG (Figure 6d) shifted to $532.02(\mathrm{C}-\mathrm{O})$ and $533.53(\mathrm{C}-\mathrm{OH})$ (Figure 6e), respectively, after $\mathrm{Cu}^{2+}$ ion adsorption. The results indicate that the $-\mathrm{NH}$ and $-\mathrm{OH}$ groups complexed with $\mathrm{Cu}^{2+}$ ion, and a chemical adsorption process occurred (Scheme 1).

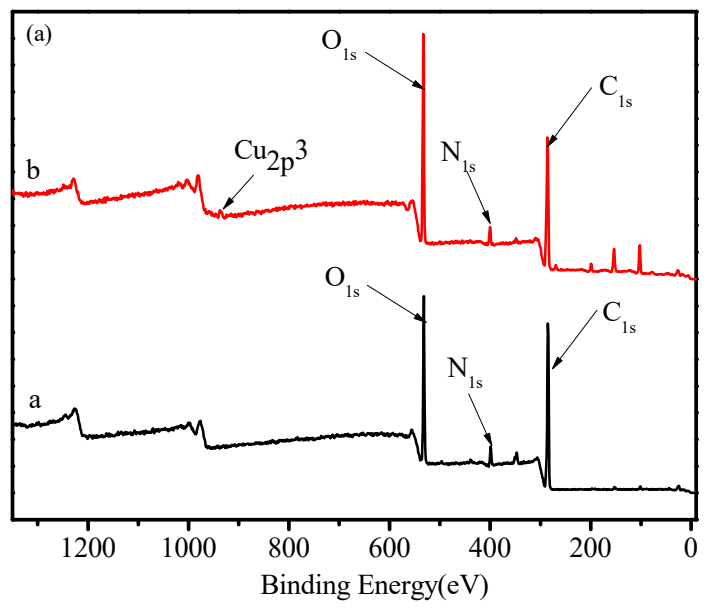

Figure 6. Cont. 

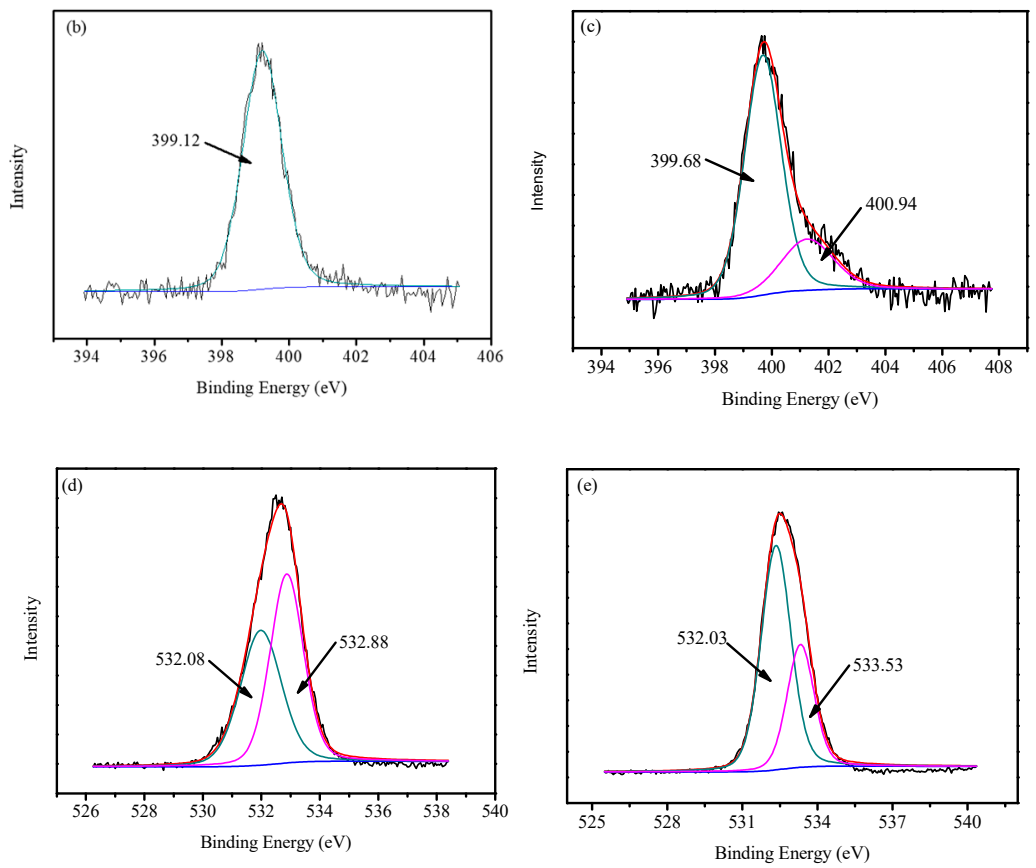

Figure 6. XPS spectra, $\mathrm{N}_{1 \mathrm{~s}}$ and $\mathrm{O}_{1 \mathrm{~s}}$ of FCG before $(\mathbf{a}, \mathbf{c})$ and after $(\mathbf{b}, \mathbf{d})$ adsorption of $\mathrm{Cu}^{2+.}$ ion.

\subsection{Batch Adsorption Experiment}

\subsubsection{Effect of $\mathrm{pH}$ of the Solution}

The adsorption of metal ion is significantly affected by $\mathrm{pH}$ of the solution, which may affect the surface charge between adsorbent and adsorbate at different $\mathrm{pH}$ value [30,31]. Figure 7 shows the effect of $\mathrm{pH}$ on the adsorption of $\mathrm{Cu}^{2+}$ ion for FCG in the $\mathrm{pH}$ range of 2-9. Initially, adsorption quantity of FCG toward $\mathrm{Cu}^{2+}$ ion increases quickly, and, after some time, the adsorption process of $\mathrm{Cu}^{2+}$ gradually reaches equilibrium. The maximum adsorption capacities are 76.03 and $41.25 \mathrm{mg} / \mathrm{g}$ when the initial concentrations of $\mathrm{Cu}^{2+}$ ion are 100 and $50 \mathrm{mg} / \mathrm{L}$ at $\mathrm{pH}=5$, respectively. $\mathrm{Cu}^{2+}$ exists in different anion species, such as $\mathrm{Cu}^{2+}, \mathrm{Cu}(\mathrm{OH})$ or $\mathrm{Cu}(\mathrm{OH})_{2}$, at different $\mathrm{pH}$ value [32]. $\mathrm{Cu}^{2+}$ is the main species at $\mathrm{pH}$ $=2-5$, while $\mathrm{Cu}(\mathrm{OH})_{2}$ is the main species at $\mathrm{pH}>5$. When $\mathrm{pH}$ value is low, competition between protons $\left(\mathrm{H}^{+}\right)$and $\mathrm{Cu}^{2+}$ for the adsorption sites of the sorbent would decease electrostatic interaction to some extent, and this electrostatic repulsion prevents the adsorption of $\mathrm{Cu}^{2+}$ ion on the surface of FCG. The protonation degree of adsorbent decreases with the increase of $\mathrm{pH}$ to neutral, the adsorption of $\mathrm{Cu}^{2+}$ ion significantly increases, and maximum adsorption capacity is observed about near $\mathrm{pH} 5$, which is attributed to the fact that a greater number of $\mathrm{Cu}^{2+}$ ions can exchange with the functional groups of FCG. Precipitation of $\mathrm{Cu}(\mathrm{OH})_{2}$ occurs between $\mathrm{Cu}^{2+}$ ion and hydroxyl ion $\left(\mathrm{OH}^{-}\right)$at $\mathrm{pH}>5$. Based on the above results, the experiments were performed at $\mathrm{pH}$ of 5 . Similar results have been reported for the capture of metal ion at different $\mathrm{pH}$ values [33-35]. The maximum adsorption capacity of $\mathrm{Cu}^{2+}$ ion with the previously reported chitosan-based adsorbents are shown in the Table 1 . It can be seen that FCG has a relatively large adsorption capacity, indicating that FCG is a fairly good material for the removal of $\mathrm{Cu}^{2+}$ ion from aqueous solution. 


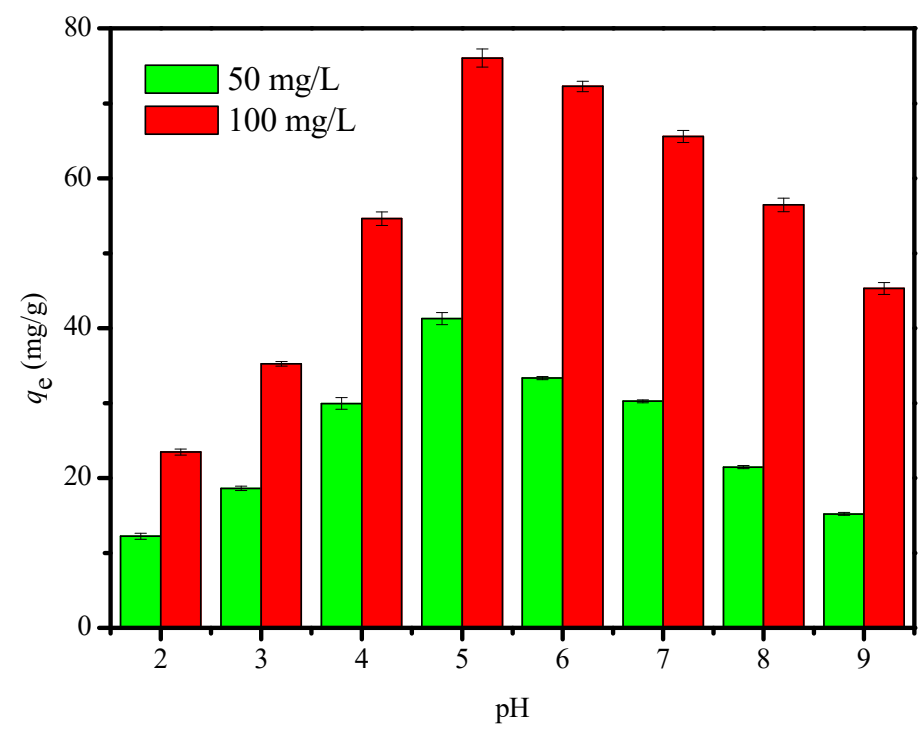

Figure 7. Effect of the solution $\mathrm{pH}$ on the adsorption of $\mathrm{Cu}^{2+}$ ion. (Initial $\mathrm{Cu}^{2+}$ ion concentration, 50 and $100 \mathrm{mg} / \mathrm{L}$; temperature, $293 \mathrm{~K}$; pH 7; agitation speed, $150 \mathrm{r} / \mathrm{min}$; and adsorbent dose, $10 \mathrm{mg} / 25 \mathrm{~mL}$.)

Table 1. Maximum adsorption capacity $(\mathrm{mg} / \mathrm{g})$ of different chitosan-based adsorbents for $\mathrm{Cu}^{2+}$ ion.

\begin{tabular}{ccc}
\hline Adsorbent & Adsorption Capacity (mg/g) & Refs. \\
\hline Thiourea-modified chitosan microspheres & 66.70 & {$[11]$} \\
Chitosan/PVA beads & 47.90 & {$[36]$} \\
Carboxymethyl chitosan-graft-D-glucuronic & 70.21 & {$[37]$} \\
acid membranes & 23.90 & {$[38]$} \\
Chitosan acetate crown ether & 53.50 & {$[39]$} \\
Chitosan/cellulose composite & 59.61 & {$[40]$} \\
Glutaraldehyde-chitosan & 31.72 & {$[41]$} \\
Chitosan/SiO $/ \mathrm{Fe}_{3} \mathrm{O}_{4}$ & 75.40 & This work \\
$\mathrm{FCG}$ & &
\end{tabular}

\subsubsection{Effects of Ionic Strength}

Effect of $\mathrm{NaCl}$ on the adsorption of $\mathrm{Cu}^{2+}$ ion is also tested by varying $\mathrm{NaCl}$ concentration from 0 to $0.030 \mathrm{~mol} / \mathrm{L}$, as shown in Figure 8. The change of $\mathrm{NaCl}$ concentration shows significant effects on the adsorption of $\mathrm{Cu}^{2+}$ ion with the different concentration. The results indicate that $q_{e}$ of $\mathrm{Cu}^{2+}$ ion increased from 54.75 and $78.80 \mathrm{mg} / \mathrm{g}$ to 79.90 and $90.02 \mathrm{mg} / \mathrm{g}$, respectively, when the $\mathrm{Cu}^{2+}$ ion concentration of 50 and $100 \mathrm{mg} / \mathrm{L}$ with increasing $\mathrm{NaCl}$ concentration from 0 to $0.030 \mathrm{~mol} / \mathrm{L}$. The increase of $\mathrm{Cu}^{2+}$ ion adsorption with higher ionic strength could be attributed to rise in activity coefficient of $\mathrm{Cu}^{2+}$ ion, decreasing the solubility of $\mathrm{Cu}^{2+}$ ion and enhancing their adsorption capacities. In addition, the increase of ionic strength might hinder the ion exchange between FCG and $\mathrm{Cu}^{2+}$ ion [42]. There was no obvious change when the $\mathrm{NaCl}$ concentration exceeded $0.025 \mathrm{~mol} / \mathrm{L}$; thus, $0.025 \mathrm{~mol} / \mathrm{L} \mathrm{NaCl}$ solution is chosen in this study. 


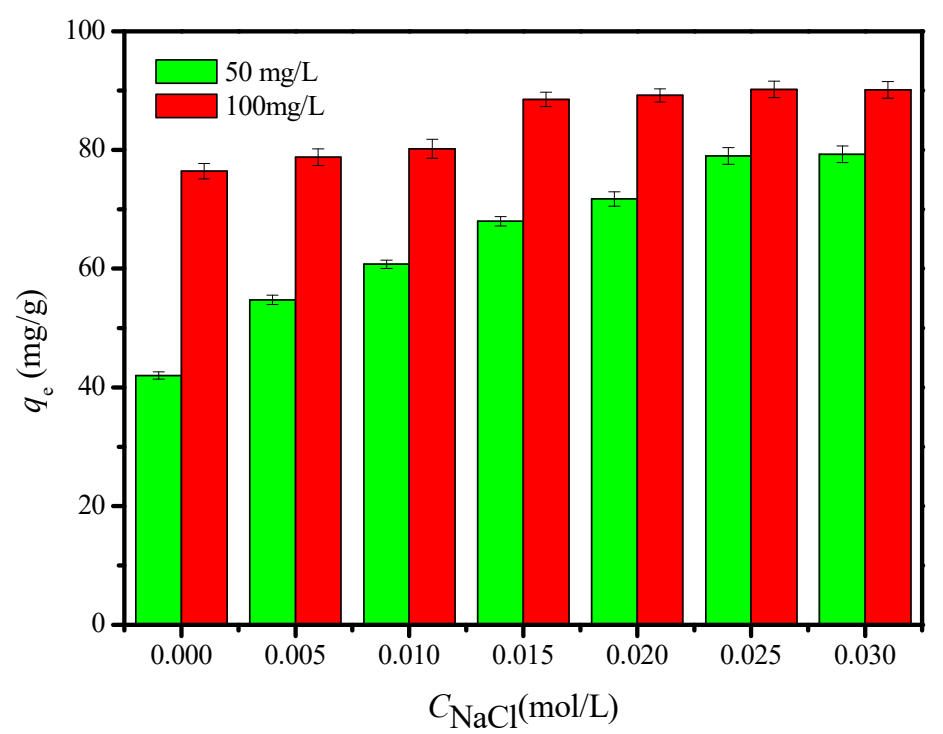

Figure 8. Effects of solution ionic strength on the $\mathrm{Cu}^{2+}$ ion adsorption by FCG. (Initial $\mathrm{Cu}^{2+}$ ion concentration, 50 and $100 \mathrm{mg} / \mathrm{L}$; temperature, $293 \mathrm{~K}$; pH, 5; agitation speed, $150 \mathrm{r} / \mathrm{min}$; and adsorbent dose, $10 \mathrm{mg} / 25 \mathrm{~mL}$.)

\subsubsection{Adsorption Kinetics}

The effects of contact time on the adsorption capacity of $\mathrm{Cu}^{2+}$ ion by FCG are shown in Figure 9. The adsorption capacity of $\mathrm{Cu}^{2+}$ ion climbs rapidly at the initial time of $100 \mathrm{~min}$ and attains high values at $500 \mathrm{~min}$. When the adsorption reaches equilibrium in $750 \mathrm{~min}$, the adsorption capacities are 39.40 and $76.42 \mathrm{mg} / \mathrm{g}$ when $\mathrm{Cu}^{2+}$ ion concentrations are 50 and $100 \mathrm{mg} / \mathrm{L}$, respectively. It might be attributed to the fact that more binding sites are readily available at the beginning of adsorption and decrease with the prolonging time. Thus, a contact time of $750 \mathrm{~min}$ was chosen in this study.

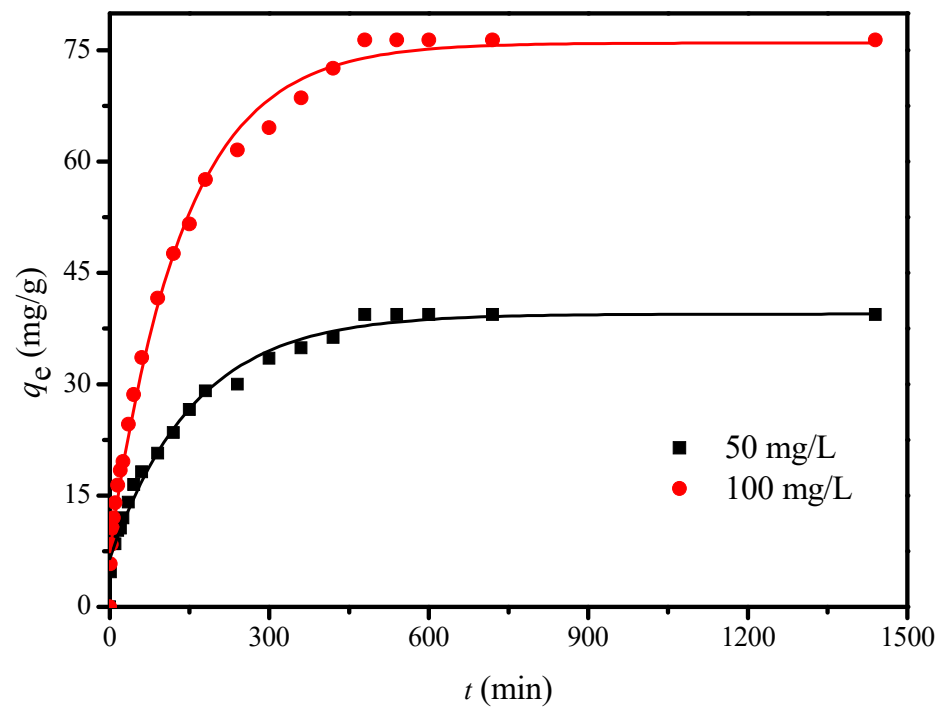

Figure 9. Effects of contact time on the adsorption capacity of $\mathrm{Cu}^{2+}$ with two $\mathrm{Cu}^{2+}$ concentration (initial $\mathrm{Cu}^{2+}$ ion concentration, 50 and $100 \mathrm{mg} / \mathrm{L} ; \mathrm{pH}$ 5; temperature, $293 \mathrm{~K}$; agitation speed, $150 \mathrm{r} / \mathrm{min}$; and adsorbent dose, $10 \mathrm{mg} / 25 \mathrm{~mL}$ ).

The three kinetic models-the pseudo-first-order, pseudo-second-order, and intraparticle diffusion models-are used to fit the adsorption kinetic data for the two $\mathrm{Cu}^{2+}$ ions, and the equations are displayed in Supplementary information. The results are shown in Figure S2, and the corresponding parameters of the kinetic models are listed in Table S3. It can be seen from Table S3 that the adsorption 
of $\mathrm{Cu}^{2+}$ ion with different $\mathrm{Cu}^{2+}$ concentration onto FCG fits the pseudo-second-order model best based on its higher correlation coefficients $R^{2}(>0.99)$. The $R^{2}$ for the intraparticle diffusion model was also lower than those of the pseudo-second-order equation. In addition, the $q_{\mathrm{e}, \text { calcd }}$ values obtained from the pseudo-second-order are consistent with the $q_{\mathrm{e}, \text { exptl }}$ values, implying that chemical adsorption is involved in the rate-limiting step of the adsorption for FCG [43]. The intraparticle diffusion model indicates three fitted linears for each concentration of $\mathrm{Cu}^{2+}$ ion, but all the straight lines have not passed through the origin, implying that $\mathrm{Cu}^{2+}$ ion adsorption is not mainly controlled by into-particle adsorption process. Adsorption of $\mathrm{Cu}^{2+}$ ion onto FCG is divided into three steps: diffusion of $\mathrm{Cu}^{2+}$ ion to the external surface of FCG; diffusion of $\mathrm{Cu}^{2+}$ ion into the pores of FCG; and adsorption of $\mathrm{Cu}^{2+}$ ion on the active sites of FCG. Similar kinetic results have been published for the adsorption of different pollutants [33,44-46].

\subsubsection{Adsorption Isotherm}

The equilibrium adsorption of $\mathrm{Cu}^{2+}$ ion on the FCG as a function of the initial concentration of $\mathrm{Cu}^{2+}$ ion is shown in Figure 10. The adsorption capacities of $\mathrm{Cu}^{2+}$ ion significantly increases with increasing the initial concentration of $\mathrm{Cu}^{2+}$ ion, and then the increasing trend becomes slower, and adsorption almost reaches a maximum adsorption value gradually. Langmuir, Freundlich, and D-R models are used to analyze the equilibrium adsorption data of $\mathrm{Cu}^{2+}$ ion on the FCG, and these models are displayed in Supplementary Information.
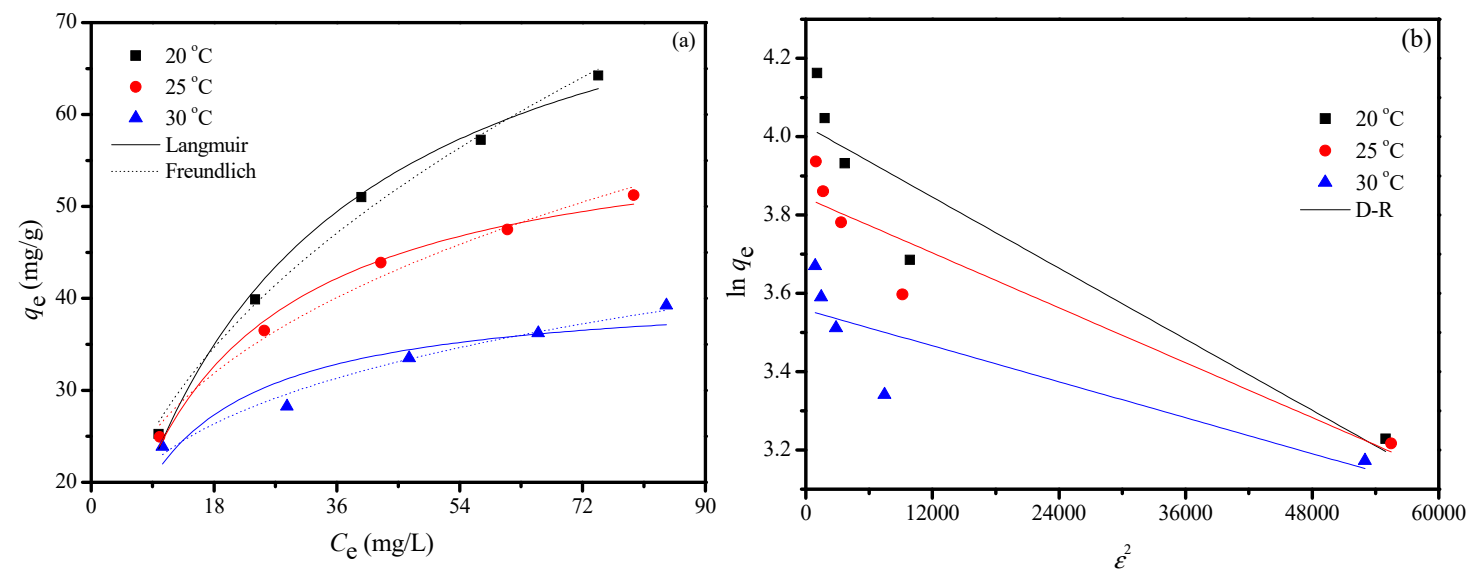

Figure 10. Isotherm model curves for the $\mathrm{Cu}^{2+}$ ion removal by the FCG; Langmuir and Freundlich model (a) and D-R model (b). (Initial $\mathrm{Cu}^{2+}$ concentration, $100 \mathrm{mg} / \mathrm{L} ; \mathrm{pH}$, 5; temperature, $293 \mathrm{~K}$; agitation speed, $150 \mathrm{r} / \mathrm{min}$; and adsorbent dose, $10 \mathrm{mg} / 25 \mathrm{~mL}$.).

Adsorption isotherms of $\mathrm{Cu}^{2+}$ ion onto FCG are shown in Figure 10, and the corresponding parameters are listed in Table S4. The Langmuir model can better describe the experimental data (Table S4) because of higher correlation coefficients (>0.99), and the maximum adsorption capacity of FCG for $\mathrm{Cu}^{2+}$ ion is calculated as $84.39 \mathrm{mg} / \mathrm{g}$, based on the Langmuir model. Separation factor, $R_{L}$, is widely used to describe the degree of suitability of adsorbent toward heavy metal ion, which can be expressed as follows:

$$
R_{L}=\frac{1}{1+K_{L} C_{O}}
$$

where $C_{\mathrm{o}}$ is the initial concentration of $C u^{2+}(\mathrm{mg} / \mathrm{L})$ and $K_{\mathrm{L}}$ is the Langmuir constant. The separation factor $R_{\mathrm{L}}$ shows the type of isotherm: irreversible $\left(R_{\mathrm{L}}=0\right)$, favorable $\left(0<R_{\mathrm{L}}<1\right)$, linear $\left(R_{\mathrm{L}}=1\right)$, or unfavorable $\left(R_{\mathrm{L}}>1\right)$ [47]. The values of $R_{\mathrm{L}}$ for $\mathrm{Cu}^{2+}$ ion adsorption onto FCG at the studied temperatures are all in the range of $0<R_{\mathrm{L}}<1$ (Table S4), implying that the capture of $\mathrm{Cu}^{2+}$ ion onto FCG is favorable [48]. The value of $R_{\mathrm{L}}$ decreases with increasing temperature, demonstrating an decrease of the affinity between $\mathrm{Cu}^{2+}$ ion and FCG. In addition, the values of the Freundlich adsorption 
isotherm constant $1 / n$ are $0.46,0.35$, and 0.24 , respectively. All the values are in the range of 0 to 1 , implying the adsorption process is favorable. $K_{f}$ values for all the temperatures are found to increase with increasing temperatures, confirming the endothermic nature of adsorption. The removal of toxic heavy metal ion, such as cadmium (II), has also been tested, and the maximum adsorption capacity of FCG for cadmium is $48.02 \mathrm{mg} / \mathrm{g}$ under the similar experimental condition. The adsorption capacity is compared with the previous adsorbents, and the comparisons are displayed in Table 2. The results indicate that FCG is also an efficient adsorbent for cadmium removal from water.

Table 2. Maximum adsorption capacity $(\mathrm{mg} / \mathrm{g})$ of different adsorbents for cadmium.

\begin{tabular}{ccc}
\hline Adsorbent & Adsorption Capacity $\mathbf{( m g / g )}$ & Refs. \\
\hline Bamboo charcoal & 12.08 & {$[49]$} \\
Red mud & 17.80 & {$[50]$} \\
Waste sludge & 15.70 & {$[51]$} \\
Almond shell & 3.18 & {$[52]$} \\
FCG & 48.02 & This work \\
\hline
\end{tabular}

\subsubsection{Thermodynamic Study}

The calculated thermodynamic parameters of FCG are listed in Table S5. Temperature is an important factor, which affects the adsorption process of $\mathrm{Cu}^{2+}$ ion. The $\mathrm{Cu}^{2+}$ ion adsorption onto FCG was studied in the range of 293 to $303 \mathrm{~K}$ (Figure 10a). The results indicate that $q_{m}$ and $K_{L}$ decrease with increasing temperatures, implying that the exothermic nature of the adsorption process. The negative $\Delta G^{\circ}$ values demonstrate the favorable and spontaneous nature of $\mathrm{Cu}^{2+}$ ion adsorption. The increase of $\Delta G^{\circ}$ with the rising temperature implies that the adsorption is more beneficial at lower temperatures. The negative $\Delta S^{\circ}$ values show the randomness at the FCG-solution interface during the adsorption. The negative $\Delta H^{\circ}$ for the removal of $\mathrm{Cu}^{2+}$ ion shows the exothermic nature of adsorption process.

\subsubsection{Regeneration Tests}

As shown in Figure S3, the adsorption capacity and recovery ratio slightly decrease with increasing the adsorption-desorption cycles. However, adsorption capacity and recovery ratio are still $72.38 \mathrm{mg} / \mathrm{g}$ and $96 \%$, respectively, after regeneration for five times. The results show that FCG has good adsorption capacity and recovery ratio for $\mathrm{Cu}^{2+}$ ion.

\section{Materials and Methods}

\subsection{Adsorbent}

Chitosan with average molecular weight 200,000 and 95\% deacetylation degree was obtained from Nantong Xincheng Biological Industrial Limited Co., Ltd., Nantong, China. Glyoxal (Gly) solution was supplied from Sigma-Aldrich (Sigma-Aldrich Chemie, Steinheim, Germany). The test material solution was prepared by dilution of $\mathrm{Cu}\left(\mathrm{NO}_{3}\right)_{2}$. Sodium borohydride $\left(\mathrm{NaBH}_{4}\right)$, hydrochloric acid $(\mathrm{HCl})$, sodium hydroxide $(\mathrm{NaOH})$, and other reagents used in this work were of analytical grade and used without further purification unless indicated. Distilled water was used throughout.

\subsection{Synthesis of FCG}

Ten milligrams of chitosan were dissolved in $1 \mathrm{~mL}$ water containing $10 \mu \mathrm{L}$ acetic acid, and $60 \mu \mathrm{L}$ glyoxal was added slowly into a three-necked flask. The mixture was stirred magnetically at $298 \mathrm{~K}$ for 1-3 min, and $333 \mathrm{~K}$ for $3 \mathrm{~h}$. After the aging for $12 \mathrm{~h}$, the obtained product was soaked in $2 \mathrm{~mL}$ of saturated solution of $\mathrm{NaBH}_{4}$ for $72 \mathrm{~h}$. After the reaction, the mixture was filtered and then washed thoroughly with large amounts of water. The resulting gel was frozen at $203 \mathrm{~K}$ for $48 \mathrm{~h}$ in a freeze-dryer. 


\subsection{Characterization of FCG}

FTIR spectra were obtained on a Bruker TENSOR 37 (Bruker, Ettlingen, Germany), with the wavenumber ranging from 4000 to $400 \mathrm{~cm}^{-1}$ and resolution of $4 \mathrm{~cm}^{-1}$. The surface morphology was characterized by field-emission scanning electron microscopy (SEM) (JEOL JSM-6700F, JEOL, Ltd., Tokyo, Japan). TG experiments were carried out on a Netzsch STA-449C thermal analysis system (Netzsch Corporation, Selb, Germany). The samples of about $3 \mathrm{mg}$ were heated at a heating rate of $10 \mathrm{~K} / \mathrm{min}$ from room temperature to $773 \mathrm{~K}$ under $\mathrm{N}_{2}$ atmosphere. The $\mathrm{X}$-ray photoelectron spectroscopy (XPS) (ESCALAB 250, Thermo Electron, Altrincham, UK) was performed with a monochromatic AlK $\alpha$ radiation source and a hemisphere detector with an energy resolution of $0.1 \mathrm{eV}$. All core-level spectra were referenced to the $\mathrm{C} 1 \mathrm{~s}$ neutral carbon peak at $284.5 \mathrm{eV}$ and obtained at a take-off $90^{\circ}$ to the sample surface. The specific surface area was determined by $\mathrm{N}_{2}$ adsorption isotherm at $203 \mathrm{~K}$, using an ASAP 2010 Micromeritics instrument and by Brunauer-Emmett-Teller (BET) method (Micromeritics Instrument Corporation, Norcross, GA, USA).

\subsection{Adsorption Experiments of $\mathrm{Cu}^{2+}$ Ion}

The adsorption of $\mathrm{Cu}^{2+}$ ion was performed at controlled $\mathrm{pH}$ and temperatures $(293,298$, and $303 \mathrm{~K}$, respectively) by shaking $0.01 \mathrm{~g}$ of dry FCG with $25 \mathrm{~mL}$ ( 50 and $100 \mathrm{mg} / \mathrm{L}$ ) of $\mathrm{Cu}^{2+}$ ion solution for $24 \mathrm{~h}$ at $200 \mathrm{r} / \mathrm{min}$. The $\mathrm{pH}$ of the $\mathrm{Cu}^{2+}$ ion solution was adjusted to the desired value with $\mathrm{HCl}$ and $\mathrm{NaOH}$. After the experiment, FCG was separated by centrifugation, and the initial and final $\mathrm{Cu}^{2+}$ ion concentration was determined with a Perkin-Elmer Analyst 700 atomic absorption spectrophotometer (AAS, Norwalk, CT, USA). The reproducibility for the data was within $5 \%$.

The adsorption capacity of FCG for $\mathrm{Cu}^{2+}$ ion at equilibrium $\left(q_{e}, \mathrm{mg} / \mathrm{g}\right)$ and the amount of $\mathrm{Cu}^{2+}$ ion adsorbed per unit mass of adsorbent at time $t\left(q_{t}, \mathrm{mg} / \mathrm{g}\right)$ were calculated as follows:

$$
\begin{aligned}
& q_{e}=\frac{\left(C_{O}-C_{e}\right)}{W} V_{O} \\
& q_{t}=\frac{\left(C_{O}-C_{t}\right)}{W} V_{O}
\end{aligned}
$$

where $C_{\mathrm{o}}, C_{t}$, and $C_{\mathrm{e}}$ are the initial concentration, the concentration at time $t$, and the equilibrium concentration in the solution $(\mathrm{mg} / \mathrm{L})$, respectively; $V_{\mathrm{o}}$ is the volume of the initial solution $(\mathrm{mL})$; and $W$ is the weight of the dry FCG $(\mathrm{g})$.

The effect of $\mathrm{pH} 3-9$, ionic strength $(0-0.030 \mathrm{~mol} / \mathrm{L})$, temperatures $(293,298,303 \mathrm{~K})$, and contact time on the adsorption capacities of $\mathrm{Cu}^{2+}$ ion were also studied.

\subsection{Kinetic Experiments}

Batch kinetic tests were performed by mixing $10 \mathrm{mg}$ of FCG with $100 \mathrm{~mL}$ of $\mathrm{Cu}^{2+}$ ion aqueous solution with concentration of 50 and $100 \mathrm{mg} / \mathrm{L}$ with original $\mathrm{pH}$ of the solution at $200 \mathrm{r} / \mathrm{min}$ for the predetermined time. Then, the temperature of the mixture was kept at $293 \mathrm{~K}$ in a bath at constant temperature for $24 \mathrm{~h}$ of shaking. After adsorption, $0.5 \mathrm{~mL}$ of aliquots was taken at various time intervals, filtered through a $0.22 \mu \mathrm{m}$ membrane, and diluted by using water. The residual $\mathrm{Cu}^{2+}$ ion concentration in the filtrate was analyzed by AAS, and the adsorption capacity was calculated by using Equation (3).

\subsection{Adsorption Isotherm}

About $10 \mathrm{mg}$ of FCG was mixed with $25 \mathrm{~mL}$ of $\mathrm{Cu}^{2+}$ ion solution. The initial concentration of $\mathrm{Cu}^{2+}$ ion was $10-100 \mathrm{mg} / \mathrm{L}$. The mixture was then shaken for $24 \mathrm{~h}$, at a desired temperature $(293,298$, and $303 \mathrm{~K})$, at pH 5, until equilibrium was reached. Equilibrium concentration of $\mathrm{Cu}^{2+}$ ion was analyzed, and the equilibrium adsorption capacity was determined as Equation (3). 


\section{Conclusions}

In summary, a functional chitosan gel (FCG) was successfully synthesized. FCG is stable at RT in acidic or basic solution, in contrast to most supramolecular gels, due to the formation of $\mathrm{C}-\mathrm{N}$ covalent bonding. FCG is effective in the removal of $\mathrm{Cu}^{2+}$ ion from aqueous solution, and maximum adsorption capacity was $75.40 \mathrm{mg} / \mathrm{g}$ in the initial concentration of $100 \mathrm{mg} / \mathrm{L}$. Kinetic studies indicated that the adsorption reaction follows the pseudo-second-order kinetics; this suggests the main adsorption mechanism of chemical adsorption. The adsorption isotherms could be well fitted by the Langmuir isotherm equation. Thermodynamic parameters obtained indicated that the adsorption process is spontaneous and exothermic. After regenerating five times, the adsorption capacity was $72.38 \mathrm{mg} / \mathrm{g}$, and the respective recovery ratio reached $96 \%$. FTIR and XPS analysis revealed that the strong electrostatic interaction between the $-\mathrm{NH}$ and $-\mathrm{OH}$ groups and $\mathrm{Cu}^{2+}$ ion are the main adsorption mechanisms.

Supplementary Materials: The following are available online. Adsorption model fitting; Figure S1. Adsorption-desorption isotherms of $\mathrm{N} 2$ at $77 \mathrm{~K}$ and pore-size distribution of chitosan and FCG; Figure S2. Adsorption kinetic equations fitting of $\mathrm{Cu}^{2+}$ ions with two $\mathrm{Cu}^{2+}$ ions concentrations by FCG; Figure S3. Regeneration capacityand recovery ratio of FCG for $\mathrm{Cu}^{2+}$ ion; Table S1. Solubility and swelling of chitosan and FCG; Table S2. Porosity and diameter of chitosan and FCG; Table S3. Kinetic parameters for the adsorption of two $\mathrm{Cu}^{2+}$ ions concentrations at $293 \mathrm{~K}$; Table S4. The correlated parameters for the adsorption of $\mathrm{Cu}^{2+}$ ions onto FCG from aqueous solution according to Langmuir, Freundlich and D-R models; Table S5. Thermodynamic parameters for adsorption of $\mathrm{Cu}^{2+}$ ions on FCG.

Author Contributions: Methodology, investigation, and writing, Z.Y.; original draft preparation, Y.C.; data curation and validation, L.Z. and Z.G.; data curation, funding acquisition, and project administration, H.J.; writing — review and editing, J.Z.

Funding: This work was preliminarily supported financially by the National Natural Science Foundation of China (2191101377, 21425627, 21376279), National Natural Science Foundation of China-SINOPEC Joint fund (U1663220), Natural Science Foundation of Guangdong Province (2017A030313057), and Guangdong Technology Research Center for Synthesis and Separation of Thermosensitive Chemicals (2015B090903061).

Conflicts of Interest: The authors declare that they have no conflict of interest.

\section{References}

1. Dong, J.; Du, Y.; Duyu, R.; Shang, Y.; Zhang, S.; Han, R. Adsorption of copper ion from solution by polyethylenimine modified wheat straw. Bioresour. Technol. Rep. 2019, 6, 96-102. [CrossRef]

2. Ali, B.M.; Wang, F.; Boukherroub, R.; Lei, W.; Xia, M. Phytic acid-doped polyaniline nanofibers-clay mineral for efficient adsorption of copper (II) ions. J. Colloid Interface Sci. 2019, 553, 688-698. [PubMed]

3. Meena, A.K.; Mishra, G.; Rai, P.; Rajagopal, C.; Nagar, P. Removal of heavy metal ions from aqueous solutions using carbon aerogel as an adsorbent. J. Hazard. Mater. 2005, 122, 161-170. [CrossRef] [PubMed]

4. Doong, R.-A.; Tsai, C.-W.; Liao, C.-I. Coupled removal of bisphenol A and copper ion by titanate nanotubes fabricated at different calcination temperatures. Sep. Purif. Technol. 2012, 91, 81-88. [CrossRef]

5. Johnson, P.D.; Watson, M.A.; Brown, J.; Jefcoat, I.A. Peanut hull pellets as a single use sorbent for the capture of $\mathrm{Cu}$ (II) from wastewater. Waste Manag. 2002, 22, 471-480. [CrossRef]

6. Taki, M.; Iyoshi, S.; Ojida, A.; Hamachi, I.; Yamamoto, Y. Development of highly sensitive fluorescent probes for detection of intracellular copper(I) in living systems. J. Am. Chem. Soc. 2010, 132, 5938-5939. [CrossRef]

7. Pehlivan, E.; Altun, T.; Parlayıc1, S. Utilization of barley straws as biosorbents for $\mathrm{Cu}^{2+}$ and $\mathrm{Pb}^{2+}$ ion. J. Hazard. Mater. 2009, 164, 982-986. [CrossRef]

8. Pehlivan, E.; Altun, T. Ion-exchange of $\mathrm{Pb}^{2+}, \mathrm{Cu}^{2+}, \mathrm{Zn}^{2+}, \mathrm{Cd}^{2+}$, and $\mathrm{Ni}^{2+}$ ion from aqueous solution by Lewatit CNP 80. J. Hazard. Mater. 2007, 140, 299-307. [CrossRef]

9. Yoo, H.; Kwak, S.-Y. Surface functionalization of PTFE membranes with hyperbranched poly(amidoamine) for the removal of $\mathrm{Cu}^{2+}$ ion from aqueous solution. J. Membrane Sci. 2013, 448, 125-134. [CrossRef]

10. Dinu, M.V.; Dragan, E.S. Evaluation of $\mathrm{Cu}^{2+}, \mathrm{Co}^{2+}$ and $\mathrm{Ni}^{2+}$ ion removal from aqueous solution using a novel chitosan/clinoptilolite composite: Kinetics and isotherms. Chem. Eng. J. 2010, 160, 157-163. [CrossRef] 
11. Wang, W.-B.; Huang, D.-J.; Kang, Y.-R.; Wang, A.-Q. One-step in situ fabrication of a granular semi-IPN hydrogel based on chitosan and gelatin for fast and efficient adsorption of $\mathrm{Cu}^{2+}$ ion. Colloid Surf. B 2013, 106, 51-59. [CrossRef] [PubMed]

12. Anbinder, P.S.; Macchi, C.; Amalvy, J.; Somoza, A. A study of the structural changes in a chitosan matrix produced by the adsorption of copper and chromium ions. Carbohydr. Polym. 2019, 222, 114987. [CrossRef] [PubMed]

13. Kumar, M.N.R. A review of chitin and chitosan applications. React. Funct. Polym. 2000, 46, 1-27. [CrossRef]

14. Zhang, L.; Zeng, Y.; Cheng, Z. Removal of heavy metal ions using chitosan and modified chitosan: A review. J. Mol. Liq. 2016, 214, 175-191. [CrossRef]

15. Cheng, Z.; Liao, J.; He, B.; Zhang, F.; Zhang, F.; Huang, X.; Zhou, L. One-step fabrication of graphene oxide enhanced magnetic composite gel for highly efficient dye adsorption and catalysis. ACS Sustain. Chem. Eng. 2015, 3, 1677-1685. [CrossRef]

16. Zhou, G.; Liu, C.; Chu, L.; Tang, Y.; Luo, S. Rapid and efficient treatment of wastewater with high-concentration heavy metals using a new type of hydrogel-based adsorption process. Bioresour. Technol. 2016, 219, 451-457. [CrossRef] [PubMed]

17. Crini, G.; Badot, P.-M. Application of chitosan, a natural aminopolysaccharide, for dye removal from aqueous solutions by adsorption processes using batch studies: A review of recent literature. Prog. Polym. Sci. 2008, 33, 399-447. [CrossRef]

18. Chiou, M.-S.; Ho, P.-Y.; Li, H.-Y. Adsorption of anionic dyes in acid solutions using chemically cross-linked chitosan beads. Dye. Pigment. 2004, 60, 69-84. [CrossRef]

19. Guilherme, M.R.; Reis, A.V.; Paulino, A.T.; Fajardo, A.R.; Muniz, E.C.; Tambourgi, E.B. Superabsorbent hydrogel based on modified polysaccharide for removal of $\mathrm{Pb}^{2+}$ and $\mathrm{Cu}^{2+}$ from water with excellent performance. J. Appl. Polym. Sci. 2007, 105, 2903-2909. [CrossRef]

20. Sivagangi Reddy, N.; Madhusudana Rao, K.; Sudha Vani, T.J.; Krishna Rao, K.S.V.; Lee, Y.I. Pectin/poly(acrylamide-co-acrylamidoGlycolic acid) $\mathrm{pH}$ sensitive semi-IPN hydrogels: Selective removal of $\mathrm{Cu}^{2+}$ and $\mathrm{Ni}^{2+}$ modeling and kinetic studies. Desalin. Water Treat. 2016, 57, 6503-6514. [CrossRef]

21. Teong, L.; Hanafiah, M.A.K.M.; Ngah, W.W. Adsorption of dyes and heavy metal ions by chitosan composites: A review. Carbohydr. Polym. 2011, 83, 1446-1456.

22. Jiang, X.; Sun, Y.; Liu, L.; Wang, S.; Tian, X. Adsorption of C.I. reactive blue 19 from aqueous solutions by porous particles of the grafted chitosan. Chem. Eng. J. 2014, 235, 151-157. [CrossRef]

23. Awual, M.R.; Eldesoky, G.E.; Yaita, T.; Naushad, M.; Shiwaku, H.; Alothman, Z.A.; Suzuki, S. Schiff based ligand containing nano-composite adsorbent for optical copper(II) ions removal from aqueous solutions. Chem. Eng. J. 2015, 279, 639-647. [CrossRef]

24. Monier, M.; Ayad, D.; Wei, Y.; Sarhan, A. Adsorption of $\mathrm{Cu}(\mathrm{II}), \mathrm{Co}(\mathrm{II})$, and Ni(II) ions by modified magnetic chitosan chelating resin. J. Hazard. Mater. 2010, 177, 962-970. [CrossRef] [PubMed]

25. Chatterjee, S.; Lee, D.S.; Lee, M.W.; Woo, S.H. Nitrate removal from aqueous solutions by cross-linked chitosan beads conditioned with sodium bisulfate. J. Hazard. Mater. 2009, 166, 508-513. [CrossRef] [PubMed]

26. Ge, F.; Li, M.M.; Ye, H.; Zhao, B.X. Effective removal of heavy metal ion $\mathrm{Cd}^{2+}, \mathrm{Zn}^{2+}, \mathrm{Pb}^{2+}, \mathrm{Cu}^{2+}$ from aqueous solution by polymer-modified magnetic nanoparticles. J. Hazard. Mater. 2012, 211, 366-372. [CrossRef]

27. Prashanth, K.H. Solid state structure of chitosan prepared under different N-deacetylating conditions. Carbohydr. Polym. 2002, 50, 27-33. [CrossRef]

28. Amsden, B.G.; Sukarto, A.; Knight, D.K.; Shapka, S.N. Methacrylated glycol chitosan as a photopolymerizable biomaterial. Biomacromolecules 2007, 8, 3758-3766. [CrossRef]

29. De Angelis, A.A.; Capitani, D.; Crescenzi, V. Synthesis and 13C CP-MAS NMR characterization of a new chitosan-based polymericnetwork. Macromolecules 1998, 31, 1595-1601. [CrossRef]

30. Brigante, M.; Avena, M. Biotemplated synthesis of mesoporous silica for doxycycline removal. Effect of $\mathrm{pH}$, temperature, ionic strength and $\mathrm{Ca}^{2+}$ concentration on the adsorption behaviour. Micropor. Mesopor. Mat. 2016, 225, 534-542. [CrossRef]

31. Fiorentin, L.D.; Trigueros, D.E.; Módenes, A.N.; Espinoza-Quiñones, F.R.; Pereira, N.C.; Barros, S.T.; Santos, O.A. Biosorption of reactive blue $5 \mathrm{G}$ dye onto drying orange bagasse in batch system: Kinetic and equilibrium modeling. Chem. Eng. J. 2010, 163, 68-77. [CrossRef]

32. Lee, M.-S.; Ahn, J.-G.; Ahn, J.-W. Recovery of copper, tin and lead from the spent nitric etching solutions of printed circuit board and regeneration of the etching solution. Hydrometallurgy 2003, 70, 23-29. [CrossRef] 
33. Wang, C.P.; Wu, J.Z.; Sun, H.W.; Wang, T.; Liu, H.B.; Chang, Y. Adsorption of Pb(II) ion from aqueous solutions by tourmaline as a novel adsorbent. Ind. Eng. Chem. Res. 2011, 50, 8515-8523. [CrossRef]

34. Liu, D.; Li, Z.; Li, W.; Zhong, Z.; Xu, J.; Ren, J.; Ma, Z. Adsorption behavior of heavy metal ions from aqueous solution by soy protein hollow microspheres. Ind. Eng. Chem. Res. 2013, 52, 11036-11044. [CrossRef]

35. Luo, P.; Zhang, J.-S.; Zhang, B.; Wang, J.-H.; Zhao, Y.-F.; Liu, J.-D. Preparation and characterization of silane coupling agent modified halloysite for Cr(VI) removal. Ind. Eng. Chem. Res. 2011, 50, 10246-10252. [CrossRef]

36. Ngah, W.W.; Kamari, A.; Koay, Y. Equilibrium and kinetics studies of adsorption of copper (II) on chitosan and chitosan/PVA beads. Int. J. Boil. Macromol. 2004, 34, 155-161. [CrossRef]

37. Jayakumar, R.; Rajkumar, M.; Freitas, H.; Kumar, P.S.; Nair, S.; Furuike, T.; Tamura, H. Bioactive and metal uptake studies of carboxymethyl chitosan-graft-D-glucuronic acid membranes for tissue engineering and environmental applications. Int. J. Boil. Macromol. 2009, 45, 135-139. [CrossRef]

38. Tan, S.; Wang, Y.; Peng, C.; Tang, Y. Synthesis and adsorption properties for metal ions of crosslinked chitosan acetate crown ethers. J. Appl. Polym. Sci. 1999, 71, 2069-2074. [CrossRef]

39. Liu, C.; Bai, R. Adsorptive removal of copper ions with highly porous chitosan/cellulose acetate blend hollow fiber membranes. J. Membr. Sci. 2006, 284, 313-322. [CrossRef]

40. Ngah, W.W.; Endud, C.; Mayanar, R. Removal of copper(II) ions from aqueous solution onto chitosan and cross-linked chitosan beads. React. Funct. Polym. 2002, 50, 181-190. [CrossRef]

41. Venkateswarlu, S.; Kumar, B.N.; Prathima, B.; Subbarao, Y.; Jyothi, N.V.V. A novel green synthesis of $\mathrm{Fe}_{3} \mathrm{O}_{4}$ magnetic nanorods using Punica Granatum rind extract and its application for removal of $\mathrm{Pb}$ (II) from aqueous environment. Arab. J. Chem. 2019, 12, 588-596. [CrossRef]

42. Jang, L.; Nguyen, D.; Geesey, G. Selectivity of alginate gel for Cu vs Co. Water Res. 1995, 29, $307-313$. [CrossRef]

43. Gupta, V.; Rastogi, A. Biosorption of lead from aqueous solutions by green algae Spirogyra species: Kinetics and equilibrium studies. J. Hazard. Mater. 2008, 152, 407-414. [CrossRef] [PubMed]

44. Yang, G.; Han, H.; Du, C.; Luo, Z.; Wang, Y. Facile synthesis of melamine-based porous polymer networks and their application for removal of aqueous mercury ions. Polymer 2010, 51, 6193-6202. [CrossRef]

45. Naushad, M.; Sharma, G.; Alothman, Z.A. Photodegradation of toxic dye using Gum Arabic-crosslinked-poly(acrylamide)/ $\mathrm{Ni}(\mathrm{OH})_{2} / \mathrm{FeOOH}$ nanocomposites hydrogel. J. Clean Prod. 2019, 241, 118263. [CrossRef]

46. Mironyuk, I.; Tatarchuk, T.; Naushad, M.; Vasylyeva, H.; Mykytyn, I. Highly efficient adsorption of strontium ions by carbonated mesoporous TiO2. J. Mol. Liq. 2019, 285, 742-753. [CrossRef]

47. Liu, B.; Lv, X.; Meng, X.; Yu, G.; Wang, D. Removal of Pb(II) from aqueous solution using dithiocarbamate modified chitosan beads with $\mathrm{Pb}$ (II) as imprinted ions. Chem. Eng. J. 2013, 220, 412-419. [CrossRef]

48. Hao, Y.-M.; Man, C.; Hu, Z.-B. Effective removal of $\mathrm{Cu}$ (II) ions from aqueous solution by amino-functionalized magnetic nanoparticles. J. Hazard. Mater. 2010, 184, 392-399. [CrossRef]

49. Wang, F.Y.; Wang, H.; Ma, J.W. Adsorption of cadmium (II) ions from aqueous solution by a new low-cost adsorbent-Bamboo charcoal. J. Hazard. Mater. 2010, 177, 300-306. [CrossRef]

50. López, E.; Soto, B.; Arias, M.; Nunez, A.; Rubinos, D.; Barral, M.T. Adsorbent properties of red mud and its use for wastewater treatment. Water Res. 1998, 32, 1314-1322. [CrossRef]

51. Lee, S.M.; Davis, A.P. Removal of $\mathrm{Cu}(\mathrm{II})$ and $\mathrm{Cd}(\mathrm{II})$ from aqueous solution by seafood processing waste sludge. Water Res. 2001, 35, 534-540. [CrossRef]

52. Bulut, Y.; Tez, Z. Adsorption studies on ground shells of hazelnut and almond. J. Hazard. Mater. 2007, 149, 35-41. [CrossRef] [PubMed]

Sample Availability: Samples of the compounds are available from the authors. 